UDC 339

JEL Classification: M31

DOI: 10.15587/2312-8372.2020.198534

\title{
Vasylchenko L. \\ ANALYSIS OF CONSUMER BEHAVIOR FORMATION MODELS UNDER THE INFLUENCE OF MARKETING COMMUNICATION ENVIRONMENT OF THE ENTERPRISE
}

Об’єктом дослідження є вплив маркетингового комунікаційного середовища підприємства на моделі формування поведінки споживачів. Дослідження такого впливу в умовах сьогодення набуває все більшої перспективності та зумовлене, передусім, підвищенням ролі маркетингових комунікацій у просуванні товарів та послуг підприємства. Застосування наукових підходів до формування поведінки споживача дозволить більш точно визначити свою цільову аудиторію. Це зумовить підвищення ефективності рекламної кампанї підприємства. При написанні роботи були використані такі методи та підходи, як логічне узагальнення, аналіз і синтез для обгрунтування концептуальних підходів до формування поведінки споживачів. А також метод групування - для упорядкування методологічних підходів до дослідження споживащької поведінки.

У роботі проаналізовано різницю між прийняттям споживацьких рішень про купівлю товару та комунікаційною компонентою маркетингу у відносинах бізнес-моделей В2В та В2С. Зокрема зазначено, що індустріальні споживачі в бізнес-моделі В2В схильні до впливу корпоративного маркетингу, який відображає не особисті інтереси, а інтереси господарюючих суб'єктів. При щьому сама бізнес-модель в сегменті В2В направлена на підтримку стійких, і взаємовигідних відносин між економічними суб'єктами як стратегічними партнерами за допомогою певного набору методів та інструментів. Автором систематизовано основні методологічні підходи до дослідження споживащької поведінки та ї моделі, які в загальному вигляді можна поділити на дві укрупнені групи: психографічні (ціннісні або стильові) та товарні або предметні.

У роботі аргументовано, що вдале використання розглянутих моделей є дієвим інструментом маркетингових комунікацій, використання якого дозволить підвищити ефективність рекламної кампанії, дасть змогу перетворити потениійних споживачів на реальних. Це, в подальшому, призведе до збільшення обсягів реалізацї продукцї (послуг) та підвищення конкурентоспроможності підприємства.

Ключові слова: маркетингові комунікації, поведінка споживачів, споживацькі рішення, комунікаційне середовище підприємства, індустріальні споживачі, індивідуальні споживачі.

Received date: 08.11.2019

Accepted date: 03.12.2019

Published date: 28.02.2020
Copyright (C) 2020, Vasylchenko L. This is an open access article under the CC BY license (http://creativecommons.org/licenses/by/4.0)

\section{Introduction}

The study of the impact of the marketing communication environment on consumer behavior in today's conditions is becoming increasingly relevant and is due to the increasing role of marketing communications in the promotion of goods and services of an enterprise. In the 1970s studies of consumer behavior were based on the theory of attitudes [1]. At the same time, work appeared related to the influence of the family on the decision to purchase, as well as the psychographics of the consumer and lifestyle as the principles of segmentation [2]. At the same time, attempts were made to cover consumer behavior through the prism of behavioral psychology and the postmodern concept [3, 4]. So, the object of research is the influence of the marketing communication environment of the enterprise on the model of formation of consumer behavior. The aim of research is to substantiate the foun- dations of the formation of consumer behavior under the influence of the marketing communication environment of the enterprise.

\section{Methods of research}

When writing the work, the following methods and approaches were used:

- logical generalization, analysis and synthesis - for justification of conceptual approaches to shaping consumer behavior;

- grouping method - for compiling methodological approaches to the study of consumer behavior.

\section{Research results and discussion}

Speaking about the constant contacts of two key actors in the market (consumer and producer), it should be 
noted that they all arise and are concentrated in the marketing plane [5]. Numerous definitions of an individual purchasing decision are presented in the scientific literature on marketing and consumer behavior, determine the similarity of research approaches, which consider the following stages of this process:

1) awareness of need;

2) information search;

3) pre-purchase estimates of options;

4) purchase decision;

5) purchase;

6) consumption;

7) reaction to the purchase;

8) evaluation of alternatives after purchase.

The adoption of consumer decisions on the purchase of goods and the communication component of marketing will be different in the relationship of the $\mathrm{B} 2 \mathrm{~B}$ and $\mathrm{B} 2 \mathrm{C}$ business models. The differences of consumers are the basis for the formation of differences of their behavior and are determined in accordance with the perceptions of consumers as:

- «biological individuals» (gender, weight, reaction rate, temperament, psychomotor);

- «social individuals» (biography, experience, character, traditions of perception, national mentality, tastes, preferences);

- «economic personalities» (hierarchy of consumption of goods, correlation of the value of commodities, methods of consumption, professional characteristics, degree of economic activity).

These differences make it possible to segment consumers by the essential features of consumption and consumer behavior.

It should be noted that the typification of consumers occurs in the scientific literature and according to other criteria, for example, their division into:

- individual (individuals, families, households);

- industrial (manufacturing enterprises, enterprises using goods for subsequent sale or rental, non-profit institutions) [6-8]. Inherent in all categories of buyers is the formation of a consumer attitude to the subject of market exchanges, information about which is transmitted by marketing communications, and the consumer attitude to purchase takes on a complete character in consumer behavior. But, unlike individual consumers (in the $\mathrm{B} 2 \mathrm{C}$ model), industrial consumers (in the B2B business model) are influenced by corporate marketing, which reflects not the personal (family, group) interests, but the interests of the business entities of which these consumers are representatives. The business model in the B2B segment is aimed at maintaining stable and mutually beneficial relations between economic entities as strategic partners using a specific set of methods and tools. The rapid development of information and communication technologies, the exponential increase in the amount of information and Internet users have significantly expanded the use of communication channels. This gives additional opportunities to increase the number of contacts with remote geographically counterparties, as well as increase the intensity of information exchange and accelerate any transactions within the B2B segment.

Marketing communications in the B2B model involve, first of all, the formation of awareness and emotional ex- perience of their addressee (i. e. collective consumers), which form the advantages of specific goods or services, organizations, forms and methods of selling goods, and the like. From the position of a «corporate» consumer, communication tools are used not only to create the advantages of a product of a particular commodity producer or goods or services of a retailer, but also are aimed at meeting specific problems, such as:

- cost reduction;

- optimization of resource potential;

- increase in labor productivity, quality of end products.

That is, the purpose of marketing communications for organizations and enterprises, as industrial consumers, has a wider range of use than for individual consumers who are interested in solving their problems with the help of a specific product.

This position can be confirmed by the position of well-known American marketers, who argue that «...relations in the $\mathrm{B} 2 \mathrm{~B}$ sector are a complex interaction that is influenced by the most diverse participants...». Such a holistic marketing approach assumes the presence of external and internal marketing, as well as interaction marketing; the relations between the three most important market participants intersect: the company, customers and intermediaries. External marketing is associated with ongoing work in the field of pricing, distribution and promotion of goods and services to customers. Internal marketing includes all the actions with the help of which training and motivation of intermediaries takes place, allowing them to turn into real messengers of marketing communications [9]. The company directly affects the work with external and internal communications, and the marketing of interaction, mainly internal marketing measures aimed at transferring communications with consumers to the level of personal relationships. Therefore, interacting with product consumers in the B2B segment, the authors recommend using corporate, marketing, and interactive communication tools [9].

Thus, the use of these types of communications in an integrated form, which modern economics refers to marketing, in the marketing environment of the enterprise will provide for partners in the B2B segment:

- leveling the influence of the factor of spatial localization;

- reduction of time for finding partners for the development of new products and transactions;

- reducing the asymmetry of information (its incompleteness and uneven distribution) and, as a result, reducing information transaction costs;

- streamlining the management structure, including vertically, reducing and combining a number of functions, and solidifying responsibility.

Another model that explains the formation of consumer decisions about the purchase of goods is the $\langle 4 \mathrm{C} \gg$ model, the author of which is considered R. Lauterborn. The main elements of the $4 \mathrm{C}$ model are:

- Customer Solution, in a broader sense, this includes not only the decision of the buyer and consumer, but also persons who influence the decision to purchase the product;

- Customer Cost, as a rule, includes the price of the product, costs of use and costs after use;

- Convenience - goods and services must satisfy a certain basic need, as well as create additional benefits 
for the consumer, forming in each case the most profitable «set» of product levels, taking into account the emotional component;

- Communication - the entire range of communications between the buyer and seller, manufacturer and consumer [10]. This model, due to its customer focus, reorientation from the price to the value for the consumer that the product can satisfy, has gained great popularity.

In the context of the informational development of society, another 7C model appeared, which is aimed at interacting with consumers in the Internet space, its elements are: Communication, Customer Care, Connectivity, Community, Convenience, Content, Customization [11].

The use of marketing communications as part of the elements of the $4 \mathrm{C}$ model proves the importance and necessity of using communication tools in consumer marketing, the use of which allows to:

- create a database of the benefits of individual (group) consumers;

- organize the work of the marketing service of the enterprise from the standpoint of responsibility for the satisfaction of consumer needs;

- customize commodity production and sales offer, taking into account the personification of consumer needs;

- influence the formation of a system of consumer values, loyalty, trust and commitment of consumers to a specific product, organization, producer or trading partner;

- use innovative information technologies to establish direct personal communications with consumers through interactive marketing communications.

It should be emphasized that the use of models in the $\mathrm{B} 2 \mathrm{~B} / \mathrm{B} 2 \mathrm{C}$ segment and the $4 \mathrm{C} / 7 \mathrm{C}$ marketing mix in the marketing communication environment of an enterprise makes it possible to use such a marketing phenomenon as integrated marketing communications.

The prerequisites for their appearance were the complication of relations between the main stakeholders of the enterprise:

- reduction of product life cycles;

- high dynamics of changes in needs;

- decrease in the effectiveness of mass advertising;

- shifting the emphasis of marketing activities of enterprises towards increasing the value of goods for consumers;

- determination of the stability of the target consumer segment as one of the key competitive advantages of the enterprise. Therefore, the model of integrated marketing communications, which is proposed for use at the enterprise, is a combination of various means, tools and technologies of communication impact on target consumer audiences in order to form the expected consumer behavior and its timely correction.

There are various methodological approaches to the study of consumer behavior, which in various ways explain the target settings of consumers and the use of means for their implementation. They also show the existing differences in patterns of behavior that are prioritized by values that determine the lifestyle of the consumer or goods, that is, direct commodities.

The methodological approaches to the study of consumer behavior and its models in Table 1 are systematized.
Table 1

Methodological approaches to the study of consumer behavior

\begin{tabular}{|c|c|}
\hline $\begin{array}{l}\text { Consumer } \\
\text { behavior } \\
\text { approaches }\end{array}$ & Consumer behavior models \\
\hline Synergistic & $\begin{array}{l}\text { Psychographic models: } \\
\text { - AID (activities, interests, opinions); } \\
\text { - VALS (values and life styles); } \\
\text { - LDV (list of values); } \\
\text { - PAIZM - model of analysis of geostyles of residents; } \\
\text { - Global Scan - a model of global life styles }\end{array}$ \\
\hline Institutional & \multirow{3}{*}{$\begin{array}{l}\text { Commodity (subject): } \\
\text { - multi-attribute (compensatory); } \\
\text { - model of an ideal product; } \\
\text { - model of non-compensatory decision-making rules; } \\
\text { - lexicographic }\end{array}$} \\
\hline $\begin{array}{l}\text { Economic: } \\
\text { - cardinalistic; } \\
\text { - ordinal }\end{array}$ & \\
\hline Motivational & \\
\hline
\end{tabular}

All the considered methodological approaches to the study of consumer behavior, which are studied in Table 1 , create a common methodological contour for highlighting patterns of consumer behavior, which in general terms can be divided into two enlarged groups:

1) psychographic (value style);

2) commodity or subject.

The AIO model divides consumers into segments according to the following parameters: activities, interests, opinions. The LOV model (list of values) forms nine values (self-realization, excitement, sense of achievement, self-esteem, sense of belonging, respect from others, safety, pleasure and fun, warm relations with others) [12]. The model of analysis of geo-style residents - PRIZM. Global lifestyle model - Global Scan. The most famous value model is the VALS (values and life styles) model, which is based on the analysis of values, relationships, ways of using resources and the rhythm of consumers' lives.

The multi-attribute (compensation) model assumes that the consumer acts as if evaluating each characteristic of the product and the brand for compliance with these signs. Regarding the ideal product model, the consumer evaluates product alternatives until one of them is identified as «real», which it prefers. The varieties of the model of noncompensatory decision-making rules are the conjunctive and disjunctive models, in which the consumer choice is divided into groups of acceptable or unacceptable alternatives, without knowing the mandatory ranking of preferences. According to the conjunctive principle of the decision-making process, the consumer sets the minimum levels of all signs or selection criteria. A product is perceived by the consumer only if each sign or selection criterion corresponds to a minimum level or exceeds it. According to the lexicographic model, the consumer evaluates the signs or selection criteria from the most important to the less important, then selects the product that is better represented by the most important criterion.

\section{Conclusions}

In the course of the study, it is argued that, with the help of consumer decision management models, enterprises can, using marketing communications, examine their target audience more deeply, adjust consumer behavior in a way that is favorable for the enterprise. This will increase the effectiveness of the advertising campaign, will turn potential consumers into real ones, which in the future 
will lead to an increase in sales of products (services) and increase the competitiveness of the enterprise.

The research results will be useful to enterprise managers, marketers, scientists involved in the study of marketing communications of the enterprise.

\section{References}

1. Fishbein, M.; Fishbein, M. (Ed.) (1967). Attitude and the prediction of behavior. Readings in attitude theory and measurement. New York: Wiley, 499

2. Ganter, B., Fernham, A. (2001). Tipy potrebitelei: vvedenie v psihografiku. Saint Petersburg: Piter, 304.

3. Hirschman, E. C., Holbrook, M. B. (1992). Postmodern Con sumer Research. Newbury Park: Sage Publications. doi: http:// doi.org/10.4135/9781483325941

4. Holbrook, M. B. (1995). Consumer Research. Thousand Oaks: Sage Publications, 410.

5. Vasylchenko, L. S. (2019), Enterprise marketing communications: genesis and stage stages. Zbirnyk naukovykh prats Cherkaskoho derzhavnoho tekhnolohichnoho universytetu. Seriia: Ekonomichni nauky, 55, 66-73.
6. Soloviov, I. O., Turkot, T. I. (2004). Rynok prodovolchykh tovariv: hlyboka sehmentatsiia spozhyvachiv. Marketynh $v$ Ukraini, 5, 4-8.

7. Oklander, M. A., Zharska, I. O. (2014). Povedinka spozhyvacha Kyiv: Tsentr uchbovoi literatury, 208.

8. Prokopenko, O. V., Troian, M. Yu. (2008). Povedinka spozhyvachiv. Kyiv: Tsentr uchbovoi literatury, 176.

9. Kotler, P., Pfoertsch, W. (2006). B2B Brand Management Springer, 357. doi: http://doi.org/10.1007/978-3-540-44729-0

10. McClean, R. (2012). The C's and P's of Marketing. What's the Difference? Available at: https://www.customfitonline.com/ news/2012/10/19/4-cs-versus-the-4-ps-of-marketing/

11. Rayport, J. F., Jaworski, B. J. (2003). Introduction to e-commerce. McGraw-Hill Irwin Marketspace, 516.

12. Popova, L. O., Mitiaieva, T. L. (2008). Povedinka spozhyvachiv. Kharkiv: KhDUKhT, 170.

Vasylchenko Lidiya, PhD, Associate Professor, Department of Economic Cybernetics and Marketing, Cherkasy State Technological University, Ukraine, e-mail: Vasilchenko_l_s@ukr.net, ORCID: http:// orcid.org/0000-0001-6262-6680 